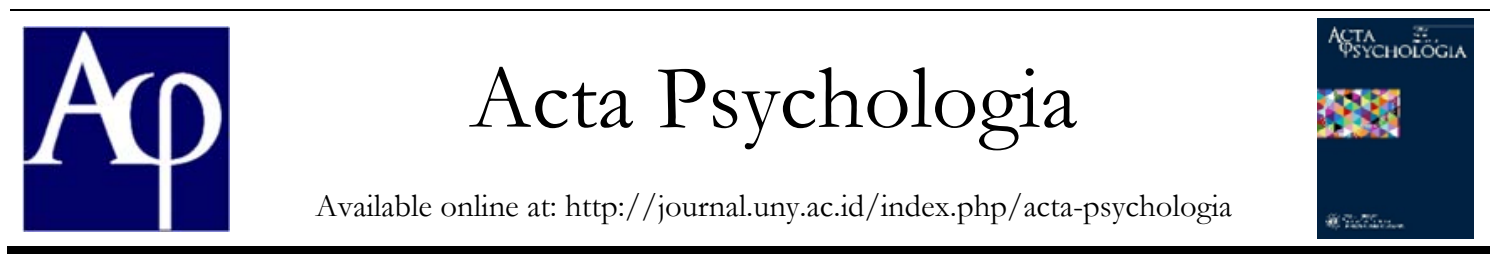

\title{
Work Engagement sebagai Prediktor Turnover Intention pada Karyawan Generasi Millennial di PT Tri-Wall Indonesia
}

\author{
Rabmad Setyo Wicaksono \\ Jurusan Psikologi, Universitas Negeri Yogyakarta; Jl. Colombo No. 1 Sleman Yogyakarta, 55281 \\ rahmadsetyowicaksono1@gmail.com
}

\begin{abstract}
Abstrak
Penelitian ini dilakukan berdasarkan adanya fenomena tingginya turnover intention pada perusahaan yang salah satunya dimungkinkan disebabkan rendahnya work engagement, oleh sebab itu penelitian ini bertujuan untuk mengetahui pengaruh work engagement terhadap turnover intention pada karyawan. Pendekatan penelitian ini menggunakan pendekatan kuantitatif dengan jenis korelasional. Populasi penelitian ini adalah karyawan operator produksi PT. Tri-Wall Indonesia yang berjumlah 100 karyawan dengan sampel penelitian sebanyak 50 karyawan generasi millennial yang ditentukan dengan teknik purposif. Metode pengumpulan data menggunakan skala. Analisis data dilakukan dengan analisis deskriptif dan analisis regresi linear sederhana. Hasil penelitian ini menunjukan bahwa terdapat pengaruh negatif work engagement terhadap turnover intention dengan $\mathrm{r}=-0,475 \mathrm{p}=$ 0,000. Variabel work engagement berkontribusi sebanyak 70,5\% terhadap turnover intention. Dalam penelitian ini partisipan memiliki tingkat work engagement sedang dengan jumlah 39 karyawan (78\%), sedangkan turnover intention memiliki tingkat sedang dengan jumlah 34 karyawan (68\%).
\end{abstract}

Kata Kunci: work engagement, turnover intention, karyawan

\begin{abstract}
This study is conducted based on the phenomenon of high turnover intention in companies, one of which is possible due to lack of work engagement. This study aims to determine the effect of work engagement on turnover intention on employees. This research uses a quantitative approach to the type of correlational. The population in this research is 100 employees of PT. Tri-Wall Indonesia. The research sample is 50 millennials employees of them determined by purposive technique. Data is collected by using scale method and analyzed by using descriptive analysis and simple linear regression analysis. The results of this study showed that there is a negative influence of work engagement on turnover intention with $r=0.475 p=0.000$. work engagement variable contributed $70.5 \%$ to turnover intention. In this study participants had a moderate level of work engagement with 39 employees $(78.5 \%)$, while turnover intention had a moderate level with 34 employees $(68 \%)$.
\end{abstract}

Keywords: work, engagement, turnover intention, employee

\section{Pendahuluan}

Karyawan sendiri sebagai sumberdaya manusia merupakan salah satu unsur penting yang dimiliki perusahaan yang berperan sebagai faktor utama penggerak roda perusahaan untuk mencapai visi-misi perusahaan. Survei yang dilakukan oleh Global Workforce Study pada periode tahun 2012 - 2 2018, kawasan Asia Pasifik diperkirakan mengalami lonjakan terbesar tingkat pergantian karyawan di tahun 2014 yaitu sebesar 21,5\% (Watson, 2014). Menurut Kapoor (2013), taksiran angka tingkat turnover di Indonesia berdasarkan sebuah perusahaan konsultasi manajemen dan survei internasional (Hay Group) pada tahun 2013-2014 mencapai 25,8\%. Angka tersebut sekaligus memposisikan Indonesia sebagai negara dengan tingkat turnover tertinggi ketiga di dunia setelah India $(26,9 \%)$ dan Rusia $(26,8 \%)$. Turnover merupakan berhentinya 
keanggotaan seorang karyawan pada perusahaan tempatnya bekerja (Mobley dalam Liu, 2005). Pengertian turnover dalam penjelasan teori Fizbein dan Ajzen (dalam Liu, 2005) adalah bentuk aktual perilaku yang didorong satu-satunya prediktor yaitu adanya niat yang diinisiasi oleh pemilik perilaku turnover.

Turnover intention adalah kadar atau intensitas dari keinginan untuk keluar dari perusahaan, banyak alasan yang menyebabkan timbulnya turnover intention ini dan diantaranya adalah keinginan untuk mendapatkan pekerjaan yang lebih baik (Hartono, 2002). Zeffane (dalam Hanafiah, 2014) mengartikan turnover intention sebagai suatu niat dari karyawan untuk berhenti dari pekerjaannya secara sukarela dan menurut pilihannya sendiri. Kondisi tersebut terjadi di PT. Tri-Wall Indonesia, hal tersebut menjadi kekhawatiran perusahaan karena akan mepengaruhi kinerja perusahaan baik secara langsung maupun tidak langsung, dan dikhawatirkan juga akan menjadi cikal bakal terjadi turnover.

Memiliki karyawan yang setia serta loyal merupakan harapan setiap perusahaan agar dapat meningkatkan kinerja dan produktivitas serta tercapainya visi-misi perusahaan. Perusahaan perlu menganggap karyawan sebagai aset, bukan beban, dan bertujuan untuk menciptakan dan memelihara tenaga kerja terampil dan berkomitmen tinggi untuk meraih keuntungan kompetitif (Storey, dalam Muhyi et al, 2016, p.10). Dalam hal ini, tentu saja perusahaan harus memiliki strategi untuk mengelola dan meningkatkan kompetensi karyawan yang sangat mungkin memiliki keunikan cara bekerja yang berbeda-beda.

Gen-Y, generasi $\mathrm{Y}$ atau generasi millennial adalah generasi yang lahir pada tahun 1981-1995 (Oblinger \& Oblinger, 2005). Generasi millennial lahir dan tumbuh di zaman yang sudah serba canggih, ketika dunia menjadi serba digital dan online, generasi ini melihat dunia dengan cara yang berbeda, yaitu dengan berselancar di dunia maya sehingga tak ayal informasi yang mereka dapat lebih up-to-date. Generasi millennial, bahkan dapat melebihi generasi sebelumnya, mereka memiliki media interaksionis dengan menggunakan internet sebagai teknologi utama untuk generasi ini (Kundanis, 2003). Di lain sisi mereka (generasi millennial) juga dikenal tidak loyal terhadap suatu pekerjaan atau perusahaan, sehingga kebanyakan karyawan gen millennial hanya bertahan di sebuah pekerjaan kurang dari tiga tahun (Winastiti, 2008). Halim (2013) memaparkan kondisi para pekerja di Indonesia yaitu hanya 36\% karyawan di Indonesia yang sangat engaged.

Sathiskumar dan Karthikeyan (2014) beranggapan bahwa tantangan di dunia industri tidak hanya mempertahankan karyawan yang berbakat saja tetapi bagaimana menjadikan karyawan tersebut terikat dengan perusahaan. Dengan begitu perusahaan membutuhkan karyawan yang memiliki tingkat work engagement tinggi.

Berdasarkan uraian dan permasalahan di atas maka peneliti ingin mencari tahu mengenai work engagement sebagai prediktor terhadap turnover intention pada karyawan generasi millennial. Peneliti berasumsi bahwa work engagement dapat menjadi prediktor untuk mengetahui turnover intention yang dimiliki seorang karyawan, terkhusus karyawan generasi millennial karena karyawan generasi millennial dilabeli sebagai karyawan yang tidak loyal terhadap perusahaan dan suka berpindah tempat kerja (Gallup, 2016). Idealnya perusahaan mengharapkan karyawan yang tidak hanya memiliki kemampuan diatas rata-rata, namun juga karyawan yang memiliki keterikatan tinggi dengan perusahaan dengan harapan dapat meningkatkan produktivitas dan performansi perusahaan. Namun pada kenyataannya perusahaan sering mengalami pergantian karyawan dimana banyak karyawan yang meninggalkan perusahaan 
akibat tingkat keterikatan dengan perusahaan yang rendah.

\section{Metode Penelitian}

Jenis penelitian yang digunakan dalam penelitian ini adalah kuantitatif dengan pendekatan deskripif. Metode penelitian kuantitatif dapat diartikan sebagai metode penelitian yang berdasarkan pada sifat positivisme, digunakan untuk meneliti pada populasi atau sampel tertentu, teknik pengambilan sampel pada umumnya dilakukan secara random, pengumpulan data menggunakan instrumen penelitian, analisis data bersifat kuantitatif/statistik dengan tujuan untuk menguji hipotesis yang ditetapkan (Sugiyono, 2013).

Penelitian dilaksanakan pada bulan Agustus sampai November 2019, sedangkan pengambilan data dilaksanakan pada tanggal 16 September 2019 sampai 30 September 2019. Tempat penelitian dilaksanakan di PT. Tri-Wall Indonesia, Bekasi, Jawa Barat.

Populasi dalam penelitian ini adalah karyawan operator produksi. Jumlah populasi keseluruhan di PT. Tri-Wall Indonesia sejumlah kurang lebih 100 orang karyawan yang merupakan karyawan generasi millennial dan bukan generasi millennial. Pengambilan sampel pada penelitian ini menggunakan teknik teknik purposif. Sampel pada penelitian ini yaitu 50 orang karyawan yang merupakan generasi millennial.

Teknik yang digunakan untuk pengumpulan data pada penelitian ini adalah skala psikologi. Skala psikologi adalah suatu teknik pengumpulan data yang memiliki item-item dengan karakteristik tidak secara langsung mengungkapkan atribut yang akan diukur, melainkan mengungkap indikator perilaku dari atribut yang bersangkutan (Azwar, 2016: 6). Instrumen yang digunakan dalam penelitian ini adalah Skala Work Engagement mengguanakan alat ukur Ultrech Work
Engagement Scale (UWES) dan Skala Turnover Intention, berbentuk skala likert.

Analisis data pada penelitian ini meliputi analisis deskriptif dan uji asumsi yang terdiri dari uji normalitas, uji multikolinearitas, dan uji heteroskedastisitas. Selain itu analisis data dalam penelitian ini menggunakan regresi linear sederhana untuk menjawab hipotesis dan mengetahui prediktor X terhadap Y.

\section{Hasil Penelitian}

Analisis deskriptif digunakan untuk mengubah data ordinal menjadi data interval dengan perhitungan manual yang berdasarkan atas norma kategorisasi (Azwar, 2018).

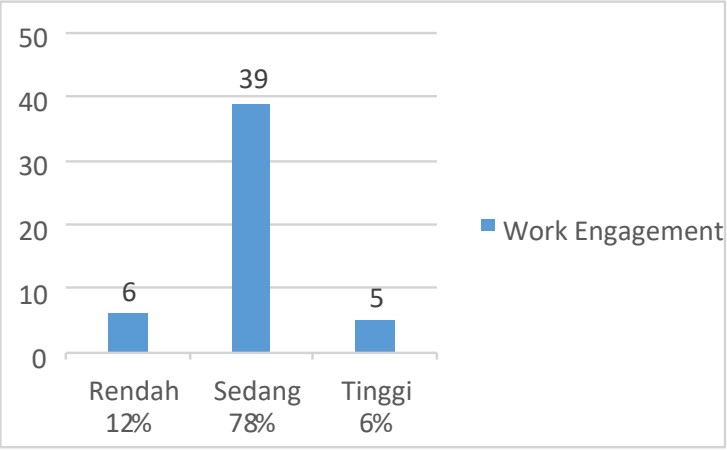

Gambar 1. Diagram Work Engagement

Berdasarkan Gambar 1. dapat diketahui frekuensi paling banyak berada pada kategori sedang, yaitu sejumlah 39 karyawan $(73 \%)$.

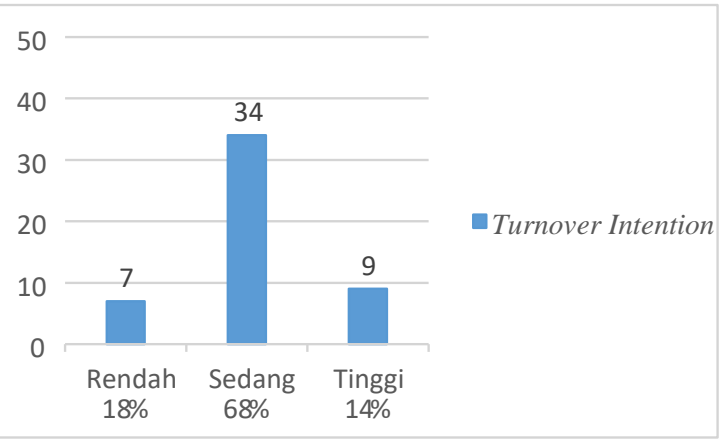

Gambar 2. Diagram Turnover Intention 
Berdasarkan Gambar 2. dapat diketahui frekuensi paling banyak berada pada kategori sedang dengan jumlah 34 karyawan $(68 \%)$.

\section{Pembahasan}

Berdasarkan hasil penelitian, work engagement dapat menjadi prediktor bagi turnover intention pada karyawan. Hipotesis yang diajukan peneliti terbukti bahwa work. engagement (X) dapat memprediksi turnover intention (Y) pada karyawan, artinya semakin tinggi work engagement maka dapat diprediksikan bahwa turnover intention pada karyawan menjadi rendah. Hasil penelitian ini sejalan dengan penelitian yang dilakukan oleh Nowack (dalam Dewantoro, 2017), karyawan yang memiliki tingkat work engagement yang lebih rendah dilaporkan memiliki turnover intention yang lebih tinggi untuk meninggalkan pekerjaan dalam kurun waktu 12 bulan.

Hasil analisis data yang lain dalam penelitian ini menunjukkan adanya sumbangan efektif work engagement terhadap turnover intention sebesar 70,5\%. Lamidi (2010) menyebutkan bahwa work engagement mempengaruhi turnover intention karena work engagement dapat menurunkan kecenderungan untuk berpindah tempat kerja. Hal ini juga sesuai dengan penelitian Wills (dalam Prihandini, 2011) yang menyebutkan salah satu cara yang dapat dilakukan untuk menekan turnover intention pada karyawan adalah dengan menumbuhkan sebuah keterikatan (engagement) pada karyawan terhadap organisasi atau perusahaan. Pernyataan ini diperkuat oleh penelitian Kahuzuma dan Schelehter (2008), bahwa penggerak engagement ketika seseorang karyawan diberikan pemberdayaan dari sistem manajemen perusahaan dalam upaya peningkatan engagement-nya terhadap perusahaan menjadi prediksi tunggal dalam mempengaruhi seorang karyawan pada saat memiliki keinginan untuk berhenti dan atau memutuskan hubungan kerja dengan perusahaan. Berdasarkan penelitian ini juga diketahui terdapat $29.5 \%$ faktor lain yang dapat mempengaruhi turnover intention pada karyawan. Faktor lain tersebut tidak diteliti dalam penelitian ini. $\mathrm{Hal}$ ini disebabkan karena work engagement bukan satu-satu faktor yang dapat mempengaruhi turnover intention pada karyawan. Hal tersebut sesuai dengan hasil penelitian yang dilakukan oleh Mobley (dalam Nisa, 2012) yang menyebutkan bahwa terdapat 2 faktor yaitu faktor organisasional dan individual. Michael (dalam Wahyuni, 2014) juga menyebutkan ada beberapa faktor yang mempengaruhi turnover intention, yaitu meliputi gaji, desain pekerjaan, pelatihan dan pengembangan, pengembangan karir, komitmen, kekompakan, kepuasan, rekrutmen, seleksi dan promosi.

Berdasarkan analisis mengenai kategorisasi masing-masing aspek dari tiap variabel. Diperoleh hasil dari variabel turnover intention yang menunjukkan aspek pemikiran untuk keluar sebesar 24,32\% yang berarti karyawan memikirkan sebelum mengambil sikap untuk keluar, karyawan akan berfikir sebelum menetapkan keputusannya tersebut. Hal ini karena mengingat mempunyai resiko kerugian atau keuntungan sebagai akibatnya. Aspek niat mencari pekerjaan sebesar 23,92\%, yang berarti karyawan memiliki keinginan untuk mencari pekerjaan diluar dari pekerjaannya sekarang. Aspek niat untuk mencari pekerjaan sebesar $51,75 \%$, yang berarti karyawan memiliki niat untuk keluar, dapat dilihat dari perilaku karyawan selama bekerja, yang biasanya diawali dengan perilaku absensi dan kemangkiran yang tinggi. Selanjutnya, perolehan hasil dari variabel work engagement, yaitu aspek vigor sebesar $14,31 \%$, yang berarti karyawan memiliki kesediaan dalam upaya untuk bekerja dan ketekunan dalam menghadapi kesulitan, ditandai dengan tingkat energi dan ketahanan mental yang tinggi saat bekerja. Aspek dedication sebesar 62,31\%, yang berarti karyawan memiliki sikap dedikasi mengacu pada identifikasi 
psikologis yang sangat kuat dengan pekerjaannya, ditandai oleh rasa signifikansi, antusiasme, inspirasi, dan tantangan yang dirasakan saat bekerja. Aspek absorption sebesar 23,46\%, yang berarti karyawan memiliki konsentrasi penuh dan larut dalam pekerjaan, dimana waktu berlalu dengan cepat dan memiliki kesulitan untuk melepaskan diri dari pekerjaan.

Berdasarkan penjelasan diatas, skor kategorisasi tertinggi dalam variabel turnover intention adalah aspek niat untuk mencari pekerjaan yang dapat dicirikan dengan perilaku karyawan melalui usaha-usaha untuk mencari pekerjaan lain seperti melihat lowongan pekerjaan melalui media informasi yang tersedia atau menanyakan informasi lowongan pekerjaan melalui kerabat maupun keluarga, dan skor kategorisasi tertinggi dalam variabel work engagement adalah dedication dicirikan dengan sifat antusiasme, kebanggan dan menginspirasi yang dikeluarkan karyawan melalui pekerjaannya, sebagai contoh karyawan akan merasa antusias setiap kali diberikan pekerjaan ataupun diminta untuk memecahkan masalah oleh atasan, atau karyawan akan memberikan inspirasi kepada rekan sejawat terkait pekerjaan yang karyawan lakukan.

Karyawan yang terindikasi memiliki turnover intention dipengaruhi seberapa besar work engagement mereka, misalnya dalam aspek vigor karyawan merasakan adanya dorongan dalam dirinya untuk terus berkarya di suatu perusahaan, dedication terhadap karirnya di perusahaan dan penghayatan yang menunjukkan makna dari apa yang dikerjakan oleh karyawan tersebut di dalam pekerjaannya, dan menurut peneliti unsur work engagement tersebut justru berasal dari materi dan tugas-tugas yang diberikan oleh perusahaan itu sendiri, sehingga karyawan mampu memaknai bahwa pekerjaan yang mereka lakukan memiliki nilai lebih dan dapat bergabung dan memberikan kontribusi terhadap perusahaan (Dewantoro \& Purba,
2017). Hal ini dikarenakan ketiga dimensi work engagement (vigor, dedication, dan absorption) memiliki hubungan yang negatif terhadap turnover intention. Ketika individu mampu untuk menemukan makna dari pekerjaan mereka, mampu bertahan pada setiap tekanan kerja yang dihadapi serta dapat terlibat penuh dalam waktu kerja yang panjang, keinginan untuk mundur atau meninggalkan pekerjaan akan semakin kecil sehingga tingkat turnover juga menurun, karena individu dapat menikmati seluruh tugas dan pekerjaannya (Gursoy, 2012).

\section{Simpulan dan Saran}

Terdapat pengaruh work engagement terhadap turnover intention $(\mathrm{p}<0.05)$. Hal ini berarti bahwa apabila karyawan memiliki work engagement tinggi maka turnover intention rendah. Apabila diketahui karyawan memiliki work engagement rendah maka turnover tinggi.

Perlu adanya peningkatan work engagement karyawan agar niat atau keinginan karyawan untuk berhenti, pindah, atau keluar dari perusahaan menurun. Untuk meningkatkan work engagement, perusahaan dapat meningkatkan pemberian fasilitas yang dapat menunjang kinerja karyawan, seperti promosi jabatan, kenaikan gaji, dan diharapkan perusahaan dapat memberikan tunjangan kepada kepada karyawan berupa asuransi. Selain itu untuk menekan perilaku turnover intention, perusahaan turut melibatkan karyawan terhadap kebijakankebijakan perusahaan, dengan begitu karyawan akan merasa engage dengan perusahaan sebab karyawan terlibat langsung dalam menentukan arah masa depan perusahaan. Perusahaan juga harus lebih mendengarkan aspirasi yang dikeluarkan karyawan, dengan begitu akan tercipta kodisi kekeluargaan yang baik, karena dalam sebuah organisasi kerja sama dan komunikasi yang baik merupakan kunci dari sebuah kesuksesan. 
Melalui hasil penelitian ini, peneliti lain dapat mengaplikasikan variabel bebas lain untuk melihat bagaimana pengaruhnya dengan turnover intention, karena dalam penelitian ini besarnya pengaruh yang didapat tidak terlalu tinggi. Selain itu, peneliti lain diharapkan dapat meminimalisir bias yang terjadi karena kurangnya interaksi dengan karyawan. Cara yang dapat dilakukan yaitu dengan memberikan angket skala psikologis ketika jam istirahat dan meminta izin perusahaan untuk melakukan wawancara dan observasi awal, serta mendampingi responden ketika mengisi angket skala psikologis. Cakupan generalisasi yang luas juga dapat dilakukan karena mampu menjawab permasalahan untuk semua divisi yang terdapat di dalam perusahaan.

\section{Daftar Pustaka}

Aguenza, B. B \& Som, A. P. M. (2012). Motivational Factors of Employee Retention and Engagement in Organizations. International Journal of Advances in Management and Economics. 1 (6). 88-95 6

Alkahtani, Ali Husein. (2015). Investigating Factors that Influence Employees' Turnover Intention: A Review of Existing Empirical Works. International Journal of Business and Management, Vol. 10, No. 12, 1833819.

Arikunto. 2006. Prosedur Penelitian Suatu Pendekatan Praktek. Jakarta : PT. Rineka Cipta.

Arianto. 2001. Analisis faktor-faktor yang mempengaruhi Turnover Intention Pada Staffkantor Akuntan Publik. Jurnal Akuntansi dan Keuangan. 2(6), pp: 102-125.

Azwar, Saifuddin. 2003. Metode Penelitian. Yogyakarta: Pustaka Pelajar.

Azwar, Saifuddin. 2007. Metode Penelitian. Yogyakarta: Pustaka Pelajar.
Azwar, Saifuddin. (2009). Penyusunan Skala Psikologi. Yogyakarta: Pustaka Pelajar.

Azwar, Saifuddin. 2016. Metode Penelitian. Yogyakarta: Pustaka Pelajar.

Bakker, Arnold. B., Leiter, Michael. P. 2010. Work Engagement: A Handbook of Essential Theory and Research. New York: Psychology Press.

Dewantoro, Rinardus Bayu \& Purba, Sylvia Diana. 2017. Pengaruh Work Engagement dan Job Satisfaction Tehadap Turnover Intention (Perbandingan Pada Generasi X dan Generasi Y). Jakarta: Universitas Katolik Indonesia Atma Jaya.

Dubas, \& Nijhawan. 2007. A Humans Capitally Theory Perspectives of Sales Force Training, Productivity, Compensation, and Turnover. Allied Academies.

Ghozali, Imam. (2011). Aplikasi Analisis Multivariate dengan program IBM SPSS 19. Edisi 5. Semarang: Badan Penerbitan Universitas Dipenogoro

Harnoto. 2002. Manajemen Sumber Daya Manusia. Edisi Kedua. Jakarta: PT. Prehallindo.

Indriyana, Faizah. (2017). Work Values Generasi Y. Semarang: Fakultas Ekonomika Dan Bisnis Universitas Diponegoro.

Kahn, W. A. 1990. Psychological conditions of personal engagement and disangagement at work. Academy of Management Journal, 33(4), 692-724.

Kahumuza, J \& Schlechter (2008). Examining the direct and some mediated relationships between perceived support and intention to quit. Journal of Management Dynamic, 17 (3), 1-19

Kular, S., Gatenby, M., Rees, C., Soane, E., \& Truss, K. (2008). Employee 
engagement: A literature review. Kingston University Working Paper Series.

Lamidi. (2010). Efek Moderasi Kepemimpinan pada Pengaruh Employee Engagement Terhadap Kepuasan Kerja. Jurnal Ekonomi dan Kewirausabaan, Vol. 10, No. 2, pp.190-200.

Macey, W. H., Schneider, B. (2008). The meaning of employee engagement. Society for Industrial and Organizational Psychology. 3- 30.

Mitchell, Thomas M. \& Schneider, Benjamin. (1984). Work and Career Considerations in Understanding Employee Turnover Intentions and Turnover: Development Of The Turnover Diagnostic. University of Maryland.

Mobley, William H., (1977). Intermediate Linkages in the Relationship Between Job Satisfaction and Employee Turnover. Journal of Applied Psychology, Vol. 62, No. 2, 237-240. University of South Carolina.

Murnianita, F. B. (2012). Pengaruh Kepemimpinan terhadap Employee Engagement pada PT PLN Persero Pusdiklat. Jakarta: Fakultas Ekonomi Universitas Indonesia.

Nugraha, Andi Muhammad Surya. (2018) Pengaruh Job Demands dan Job Resources terhadap Turnover Intention melalui Work Engagement pada Staff Karyawan RSU Dr Wahidin Sudirohusodo. Yogyakrta: Universitas Islam Indonesia.

Nugraha, Putra. (2012). Hubungan Lingkungan Kerja Kreatif Dengan Keterikatan Kerja. Jakarta: Fakultas Psikologi Universitas Indonesia.

Nugroho, Eddy., Santoso, Anwar. (2015). Pengaruh Kepuasan Kerja Dan Stres Kerja Terhadap Turnover Intention
(Studi Kasus Pada Pt. Istana Kebayoran Raya Motor Cabang Pondok Indah). Jurnal Sains Manajemen Unsera; Vol. 1, No. 2.

Nur Qalbi, Sitti. 2016. Pengaruh Job Embeddedness Terhadap Intensi Turnover Karyawan Caroline Officer PT. Infomedia Nusantara. Jurnal Psikologi Jambi. 1(7), pp: 48-54.

Nurhasan, Rohimat. (2017). Kepuasan Kerja Dan Loyalitas Generasi-Y. Jurnal Wacana Ekonomi; Vol. 17, No. 1. 013-023.

Nurhidayati, Ulfi. (2018). Hubungan Work Family Balance Dan Work Engagement Pada Karyawan Yang Berkeluarga. Yogyakarta: Fakultas Psikologi dan Ilmu Sosial Budaya Universitas Islam Indonesia. Work Engagement Sebagai .... (Rahmad Setyo Wicaksono) 7

Oblinger, D. and Oblinger, J., Eds. (2005). Educating the Net Gen. Washington, D.C.: EDUCAUSE.

Pandu Asmara, Alfatania. 2017. Pengaruh Turnover Intention terhadap Kinerja Karyawan di Rumah Sakit Bedah Surabaya. Jurnal Administrasi Kesehatan Indonesia. 5(2), pp: 123-129.

Paré, Guy and Michel Tremblay. 2001. The Measurement and Antecedents of Turnover Intention among IT Professionals, online (www.cirano.umontreal.ca/publicati on/docu ments.html, diakses 18 Oktober 2018).

Park, J., dan D. Gursoy. (2012). Generation Effects on Work Engagement among US Hotel Employees. Internation Journal of Hospitality Mangement, 1195-1202.

Prihandini, A. (2011). Faktor-faktor yang mempengarubi intensi turn over pada karyawan PT Alenatex Bandung. Jakarta: Universitas Islam Negeri Syarif Hidayatullah Jakarta 
Putra, Yanuar Surya. (2016). Theoritical Review: Teori Perbedaan Generasi. Among Makarti. Vol. 9, No. 18.

Putrianti, A. D., Hamid, Dj., Mukzam, M. D. (2014). Pengaruh Kompensasi Dan Motivasi Kerja Terhadap Turnover Intention (Studi Pada Karyawan PT. TIKI Jalur Nugraha Ekakurir Pusat Malang). Jurnal Administrasi Bisnis; Vol. 12, No. 2.

Saks, A.M. (2006). Antecendents and consequences of employee engagement. Journal of Managerial Psychology, 21 (6), 600-619.

Sathiskumar, A. S., \& Karthikeyan, P. (2014). Role of Quality Management Practice in Employee Engagement and its impact on Organizational Performance. Journal of Business Management and Social Sciences Research, 3 (10). 1-5.

Schaufeli, W. B., Bakker, A. B. (2004). Job Demands And Job Resources And Their Relationship With Burnout and Engagement: A Multi Sample Study. Jurnal of Organizational Behavior.Wiley InterScience. 293-315.

Schaufeli, W. B., \& Bakker, A. B. (2003). UWES - Utrecht Work Engagement Scale: Test manual. Utrecht. The Netherlands: Department of Psychology, Utrecht University.

Schaufeli, W, B., \& Salanova, M. (2008). A Crossnational Study of Work Engagement as A Mediator between Job Resources and Proactive Behaviour. The International Journal of Huan Resource Management (19), 116131.

Schaufeli, W. B.; Salanova, M.; GonzalesRoma; Bakker, A.B. (2002). The Meansurement of Engagement and Burnout: A Two Sample Confirmatory Factor Analytic Approach. 3, 71 - 92.
Schawbel, Dan. 2011. "Who's at Fault for High GenY Turnover?". https://www.forbes.com/sites/dans chawbel/2 011/11/22/whos-atfault-for-high-gen-y turnover/\#47cc30fe7d98. (diakses pada tanggal 11 Oktober 2018).

Sugiyono. 2013. Metode Penelitian Pendidikan Pendekatan Kuantitatif, Kualitatif, dan R\&D. Bandung: Alfabeta.

Wahyuni, S. R., Zaika, Yulvi., Anwar, Ruslin. (2014). Analisis FaktorFaktor Yang Mempengaruhi Turnover Intention (Keinginan Berpindah) Karyawan Pada Perusahan Jasa Konstruksi. Jurnal Rekayasa Sipil. Vol. 8, No. 2. 19785658.

Widodo, Rohadi. (2010). Analisis Pengaruh Keamanan Kerja Dan Komitmen Organisasional Terhadap Turnover Intention Serta Dampaknya Pada Kinerja Karyawan Outsourcing (Studi Pada PT. PLN Persero APJ Yogyakarta). Semarang; Universitas Diponegoro.

Wulan Nisa, Happy Dayantia., Suharsono, Yudi., Ingarianti, Tri Muji. (2012). Hubungan Antara Iklim Organisasi Dengan Intensi Turnover Pada Karyawan. Prosiding Seminar Nasional Peran Budaya Terhadap Efektivitas dan Efisiensi Organisasi. Badan Penerbit Universitas Maria Kudus, Kudus. ISBN 978- 60218835-2-2.

Zeffane. 2003. Organizational Behavior A Global Perspective. Australia: John Wiley and Sons Australia Ltd. Ditulis di belakang SIMPULAN DAN SARAN, dengan mengikuti gaya selingkung E-Journal, seperti tercantum dalam Guideline jurnal ini (yang meratifikasi $A P A$ Edisi IV). 